\title{
THE CONTRIBUTION OF THE CLINICAL NURSE INSTRUCTOR TO THE DEVELOPMENT OF CRITICAL THINKING SKILLS OF THE STUDENT NURSE IN NAMIBIA
}

\author{
Prof A van Dyk \\ DCur, RN \\ Senior Lecturer, Faculty of Medical and Health Sciences, University of Namibia
}

\section{Prof K Jooste}

DCur, RN

Associate Professor, School of Nursing, University of Johannesburg

\author{
Prof L Small \\ DNSc, RN \\ Senior Lecturer, Faculty of Medical and Health Sciences, University of Namibia
}

\author{
Ms L Pretorius \\ MNSc, RN \\ Lecturer, Faculty of Medical and Health Sciences, University of Namibia \\ Corresponding author: Ipretorius@unam.na
}

Keywords: critical thinking; clinical instruction; clinical nurse instructor; student nurses

\begin{abstract}
A quantitative, non-experimental and exploratory study was undertaken to determine the contribution by the clinical nurse instructor to develop critical thinking skills of student nurses in Namibia. The study was conducted at the training hospitals of Namibia, namely Windhoek, Oshakati and Onandjokwe State hospitals. Clinical nurse instructors from all disciplines were included in the study, as well as student nurses in their second, third and fourth year of undergraduate nursing study. The findings of the study revealed that, although the clinical instructors in the training hospitals of Namibia are aware of their responsibility, they do not focus on the development of critical thinking of student nurses in Namibia. A need for in-service programmes to emphasise the development of critical thinking skills of both clinical nurse instructors and student nurses was identified.
\end{abstract}

\section{OPSOMMING}

' $n$ Kwantitatiewe nie-eksperimentele en verkennende studie is onderneem om te bepaal wat die bydrae van die kliniese verpleeginstrukteur is om kritiese denke by die studentverpleegkundige in Namibië te ontwikkel. Die studie is in die opleidingshospitale van Namibië, naamlik Windhoek, Oshakati en Onandjokwe Staatshospitale uitgevoer. Kliniese verpleeginstrukteurs van alle dissiplines is by die studie ingesluit. Voorts het studentverpleegkundiges in hulle tweede, derde en vierde jaar van voorgraadse verpleegstudie aan die navorsing deelgeneem. In die studie is bevind dat, alhoewel kliniese verpleeginstrukteurs in die opleidingshospitale van Namibië van hulle verantwoordelikheid bewus is, hulle nie op die ontwikkeling van kritiese denke by die studentverpleegkundiges van Namibië fokus nie. ' $n$ Behoefte aan ' $n$ indiensopleidingsprogram is geidentifiseer om die ontwikkeling van kritiese denke, in beide die verpleeginstrukteur en die studentverpleegkundige te bevorder, was geïdentifiseer. 


\section{INTRODUCTION}

In the contemporary health care environment, characterised by rapidly changing developments and relentlessly increasing knowledge, the possession of critical thinking skills is essential in order to make sound judgment when solving problems in order to uphold the standards of professional practice (Mpaka \& Uys, 1999:15; Tiwari \& Lai, 2002).

These rapidly changing developments are also found in Namibia. Namibia has a very complex and an extensive health care scenario, which expects from any professional nurse in practice the ability to make discretionary judgments autonomously. Professional nurses in Namibia are expected to act decisively and correctly, displaying critical thinking, in order to handle problematic and complicated nursing situations. Professional nurses should be able to debate issues, solve problems and communicate their knowledge to others. In addition, nurses are expected to think critically in order to process complex data and make intelligent decisions, because nurses are confronted daily with unknown situations (Shin, 1998:414). For nurses to cope with these situations they should have the ability to integrate their nursing knowledge into nursing practice. Decisions that are then made are closely related to critical thinking.

The integration of nursing knowledge into nursing practice should eventually culminate into clinical knowledge. Lack of clinical knowledge can be very stressful for any nurse practitioner and should be avoided. It will also hamper the rendering of quality care provided by this nurse practitioner. Stress can be avoided by empowering oneself with the necessary knowledge. Personal power is the key to success to enable the individual to practice effectively and ultimately ensure a high quality of nursing care. Professional nurses are therefore empowered to control their own destiny and professional future by exercising critical thinking (Mpaka \& Uys, 1999:16). Empowerment in nursing makes it possible for nurses to realise their potential to contribute effectively to health care provision by thinking critically. In Namibia, it is essential that the student nurse is empowered through clinical instruction to obtain as much knowledge and skills as possible to face the challenges in the health care of the country. Clinical nurse instructors constantly have to re-examine their teaching to find the best way to teach and empower students for exercising critical thinking in the clinical area (Rowles \& Brigham, 1998:247).

For a nurse to be a critical thinker in nursing practice means the intentional engagement with a problem at hand, with the result that different nurses will arrive at different interpretations, depending on their critical thinking ability. Critical thinkers in nursing are truth seekers and demonstrate open-mindedness and tolerance for others' views with constant sensitivity to the possibility of their own bias. To have critical thinkers in a health care environment, it is essential that student nurses be taught during their basic education to think critically (Jones \& Brown, 1991:530; Chenoweth, 1998:283).

For the development of critical thinking skills of student nurses, the accompaniment by the clinical nurse instructor is essential. Exposure to nursing practice which is not well controlled, may lead to less than adequate development in critical thinking (Richardson, 1998:27).

Traditionally, nursing education did not encourage creativity and critical thinking. However, critical thinking is considered an advanced way of thinking, and an essential part of nursing (Hill \& Howlett, 1997:58-59). Teaching critical thinking in the practice of nursing science is a relatively new concept. This results in a situation where nurses end up after completion of their course not able to think critically, because they were not encouraged to reveal an attitude of inquiry during their education but rather an attitude of accepting everything as the truth (Harbison, 1991:406).

If experts could not come to an agreement on what critical thinking is, how would clinical nurse instructors then know their responsibility in strengthening critical thinking? The development of critical thinking in nursing students is the sole responsibility of the clinical nurse instructor and should become one of the major goals in higher education (Conger \& Mezza, 1996:12).

Critical thinking is fast becoming the new focus for education at all levels of the educational system, and it is necessary to realise that critical thinking is not exercised in a vacuum, but forms part of the educational milieu of any nurse practitioner (Miller \& Malcolm, 1990:69). 


\section{LITERATURE REVIEW}

The literature review is organised within the framework of the development of critical thinking during clinical instruction in nursing practice. Clinical practice involves a set of skills that have to be taught by clinical nurse instructors during the training of student nurses. This creates the expectation that clinical nurse instructors should be knowledgeable in order to provide a positive role model to the students in this regard.

Knowledgeable clinical instructors will stimulate students to become creators of their own knowledge. This however is part of a learning culture that needs to be promoted because students in general, and also in Namibia, come from an era where it was the practice to passively receive information and knowledge without being an active participant in learning. The instructor should also display interacting skills and personal characteristics to promote learning in students and a demand to promote good teacher-learner cooperation where the student can develop self-confidence in decision-making and observation (Norton, 1998:154).

This promotion could be achieved by means of clinical instruction. Clinical instruction, as a means of teaching, can be defined as acting and interacting with nursing students, clients and other health professionals in settings where people are in need of care (Van Hoozer, 1987:75). The aim is to produce a competent professional nurse who is capable of rendering expert nursing care, based on sound knowledge and practiced skill. Indirectly this should lead to the development of critical thinking skills which include clinical judgment and observational skill. It is during clinical instruction that the nursing student should learn to differentiate and organise parts and wholes into a meaningful pattern. As has been implied in the introduction clinical instruction is not viable if not accompanied by critical thinking.

The skill of critical thinking is important for any nurse to have because it will enable nurses to understand themselves and others and to solve problems (Price, 2004:46) hence nurses in Namibia are no exception to this notion.

Clinical instruction should therefore go beyond the ensuring of proficiency in technical skills by helping students understand the underlying principles of these skills. To understand the underlying principles means that student nurses manage to think critically on why they have to do certain interventions in certain ways (Schweer \& Gebbie, 1976:84; Manzini, 1988;26). The key role player in clinical instruction is the clinical nurse instructor. This is the person responsible for enhancing critical thinking during clinical practice.

To become a critical thinker, a change towards active participation in learning is necessary to apply the theory of nursing and to reach the art and science of nursing (Schweer \& Gebbie, 1976:99; Malek, 1986:20; Burnard \& Morrison, 1993:38; Rowles \& Brigham, 1998:250).

In the care for the patient, the nurse is the one who is in contact with the patient for 24 hours. All other members of the health team come in contact with the patient for only fractions of a day. This scenario leaves the nurse with parts of care and prescriptions from different members in the health team who has seen the patient. Nurses have to organise all these fractions into a holistic nursing care plan for them to meet the needs of the patient. This however is not possible if they are not able to think critically and analytically. By exercising critical thinking, they become independent practitioners who can render quality care to their patients (Pretorius, 2001:12).

According to Burnard and Morrison (1993:10) the heart and soul of the acquisition of critical thinking is in the practical set-up. It is at the bedside of the sick that the true spirit of nursing is passed and no other teaching can take its place. Critical thinking however is not innate.

The link of critical thinking with clinical instruction in nursing is considered a challenge to the clinical nurse instructor because it calls for proper administration and leadership from the side of the instructor in order to achieve the desired outcome of high quality individualised patient care (Shah \& Polifroni, 1992:41). Harden (1996:16) emphasises that the development of a critical consciousness in the nursing student is a quintessential part of a "clinical instructors" role. She also emphasises that student nurses should be empowered through clinical instruction to think critically. The most obvious features of critical thinking in clinical instruction are rationality and reasonability which refer to the fact that thinking is based on reasons rather 
than prejudice, preference, self-interest or fears. It is important that the clinical nurse instructor should allow students to analyse "why" questions, and to have their own opinions and interpretations about situations in their caring for patients (Duldt, 1994:9).

Although the development of critical thinking skills is the ideal, it is not always realised in practice. Several studies indicated the lack of skills acquirement. Mpaka and Uys (1997:14) compared the critical thinking ability of two groups of nurses who had undergone two different nursing programmes. This study revealed that the critical thinking ability of both groups was low. The interpretation of the study reflected on the general educational background as a problem and on a lack of clinical supervision in nursing practice.

During 1999 an investigative survey was undertaken by Van den Bergh (2000:96) to establish what nursing students understand by critical thinking and to determine if there is a need amongst first year learners for critical thinking skills. According to the data analysis, the participants felt that the University should equip them with skills to think independently and critically.

Several studies have also been done to determine whether the teaching approach is efficient in the teaching of student nurses, and nursing education had been criticised that not enough emphasis is put on the development of critical thinking in the teaching of student nurses.

From the literature it is evident that nurses do not possess critical thinking skills. Health care systems, including the health care system of Namibia, need critical thinkers to discriminate and judge appropriately in difficult and sometimes chaotic circumstances. To think critically means to perform focused reasoning in order to resolve problems in health care. Critical thinking further requires that one personalise the information, analyse it and then draw conclusions around it in order to render quality care (CCRI, 2003:2).

\section{PROBLEM STATEMENT}

Student nurses registered at educational institutions in Namibia, spend 50 percent of their education period in the clinical situation. This creates the ideal situation to develop the critical thinking skills of students under the guidance of the clinical nurse instructor. Nevertheless, through working with students and following them in the practical situation, it has become evident to the researcher that student nurses are not always able to assess patients and plan nursing care situations properly, because they do not have sufficient critical and analytical thinking skills to solve problems. As an example, students also have difficulty in presenting a case study during a nursing round. The implication hereof is that patients will suffer as a result because superficial care will be rendered to them instead of well-thought out and focused care.

The researcher was interested in why students could not think critically. Was it because they were not taught during their training? The researcher then formulated the following research question: "What is the contribution of the clinical nurse instructor towards the development of critical thinking skills of student nurses?"

\section{PURPOSE OF RESEARCH}

The purpose of this study was to determine how clinical nurse instructors in the training hospitals contribute to the development of critical thinking skills of student nurses, during clinical instruction in nursing practice.

\section{OBJECTIVES OF THE STUDY}

The objectives of the study were to:

- explore and describe the contribution of the clinical nurse instructor to the development of critical thinking skills of student nurses; and

- formulate recommendations of aspects that could be included in an in-service training programme for all clinical nurse instructors.

\section{SIGNIFICANCE OF THE RESEARCH}

By sensitising the clinical nurse instructor towards strategies that will promote critical thinking skills of student nurses, the study will also assist students on ward level to become critical thinkers in the delivery of nursing care. The study will benefit all stakeholders in the training of student nurses in Namibia because the research will indicate whether the clinical nurse instructors could adapt their clinical instruction methods to promote the development of critical thinking skills of 
student nurses.

\section{KEY CONCEPTS}

Key concepts as applied to this study will be described under this section.

\section{Clinical practice}

For purposes of this study the term refers to any practice pertaining to the care of a patient that takes place in the health care setting of training hospitals/clinics in Namibia. Caregivers are expected to integrate theory and practice in the rendering of promotive, preventive, curative and rehabilitative care in the health care institutions.

\section{Clinical nurse instructor}

The term refers to "individuals providing experiences for students in the practice field, regardless of what their designation in the organization may be" (Brink, 1996:36). For this study the term refers to a clinical nurse instructor in Namibia who is dealing with clinical instruction of student nurses, involved in basic nursing studies.

\section{Critical thinking}

Critical thinking is that process that helps a nurse to decide what really matters and what is important. Critical thinking is the ability to argue a case until the best solution for the nursing problem is reached (Bandman \& Bandman, 1988:3). It is furthermore a skill that becomes an integral part of each nurse's character through acquisition of knowledge and experience. Norris and Ennis (1985:1) define the concept of critical thinking as "reasonable and reflective thinking that is focused upon deciding what to believe or do" in nursing practice. Although many definitions exist in the literature, very few were specifically defined for nursing.

\section{Student nurse}

This is a student registered under Section 21 of the Namibian Nursing Act No 30 of 1993. For the purpose of this study a student nurse refers to a student registered at the Namibian Nursing Board as a nursing student.

\section{RESEARCH DESIGN}

This study was a quantitative, non-experimental, des- criptive and exploratory study (Garbers, 1996:282), concerned with an investigation into the contribution by clinical nurse instructors to develop critical thinking skills of student nurses in Namibia.

\section{METHOD}

A survey approach was used for this study. A survey is regarded most appropriate for collecting data from a large population which cannot be observed.

\section{Population and sample}

The population for the study included all the clinical nurse instructors in the training hospitals and training institution of Namibia and all nursing students in their second, third and fourth year of study.

The clinical nurse instructors consist of different categories as outlined in Table 1, indicating the population and sample selection.

The study was conducted in the training hospitals of Namibia, namely Windhoek Central hospital and Katutura hospital as well as Oshakati and Onandjokwe hospitals in the north of the country. All nurse educators from the training institution namely the University of Namibia were included in the sample and by probability stratified random sampling, some of professional nurses from general wards and specialised units of the training hospitals were included (indicated in Table 1). Each participant had an equal chance to be included (Babbie \& Mouton, 2001:138).

\section{Data collection instrument}

The compilation of the instrument was based on the concepts of critical thinking and clinical instruction like:

- fostering of inquisitive strategies and openmindedness;

- fostering of an analytical approach to problem solving;

- $\quad$ independent decision-making; and

- identifying of learning opportunities that contribute to the utilisation of critical thinking skills.

See Table 2 for the discussion on the motivation behind the selection. 
Table 1: Population and sample selection

\begin{tabular}{|c|c|}
\hline Population & Sample \\
\hline $\begin{array}{l}\text { Category 1: } \\
\text { All nurse educators within the Faculty of Medical and Health Sciences } \\
\text { at the University of Namibia. } \\
\mathrm{N}=42\end{array}$ & $\begin{array}{l}\text { Category 1: } \\
\text { Random sampling } \\
\mathrm{N}=25\end{array}$ \\
\hline $\begin{array}{l}\text { Category 2: } \\
\text { All professional nurses in general nursing units at the training hospitals } \\
\text { in Windhoek, Oshakati and Onandjokwe. } \\
\mathrm{N}=542\end{array}$ & $\begin{array}{l}\text { Category 2: } \\
\text { Random sampling } \\
\mathrm{N}=108\end{array}$ \\
\hline $\begin{array}{l}\text { Category 3: } \\
\text { All professional nurses in the specialty units (midwifery, psychiatry and } \\
\text { community health units) at the training hospitals in Windhoek, } \\
\text { Oshakati and Onandjokwe. } \\
\mathrm{N}=244\end{array}$ & $\begin{array}{l}\text { Category } 3 \\
\text { Stratified random sampling } \\
\mathrm{N}=50\end{array}$ \\
\hline
\end{tabular}

Table 2: Motivation on selection of concepts

\begin{tabular}{|c|c|}
\hline Concept & Comments \\
\hline $\begin{array}{l}\text { Fostering of inquisitive strategies and } \\
\text { open-mindedness }\end{array}$ & $\begin{array}{l}\text { "critical thinking is the process that helps nurses to } \\
\text { decide what really matters and what is important" } \\
\text { (Bandman \& Bandman, 1988:2) } \\
\text { - "to broaden their insight, they might generate new } \\
\text { questions which the students should investigate" (Duldt, } \\
\text { 1994:9) }\end{array}$ \\
\hline $\begin{array}{l}\text { Fostering of an analytical approach to } \\
\text { problem solving }\end{array}$ & $\begin{array}{l}\text { - "a learning environment which sharpens the developing } \\
\text { of critical thinking abilities should be identified by the } \\
\text { clinical nurse instructors" (Rowles \& Brigham, 1998:247) } \\
\text { "a nurse, through critical thinking, should be able to } \\
\text { analyze a problem"(Chenoweth, 1998:283) }\end{array}$ \\
\hline Independent decision-making & $\begin{array}{l}\text { - "the nurse should make independent judgments in } \\
\text { several circumstances" (Miers, 1990:32) } \\
\text { "coping with the nursing situation will promote growth and } \\
\text { development into a competent independent practitioner } \\
\text { and to the development of a critical thinking } \\
\text { consciousness in the nursing student" (Harden, 1996:16) }\end{array}$ \\
\hline $\begin{array}{l}\text { Identifying of learning opportunities } \\
\text { that contribute to the utilisation of } \\
\text { critical thinking skills }\end{array}$ & 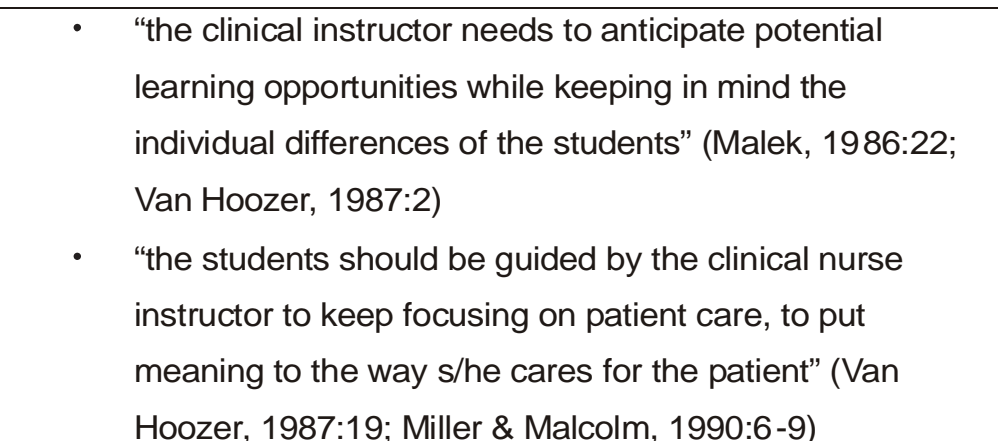 \\
\hline
\end{tabular}




\section{Reliability and validity}

To enhance reliability in this study the following measures were put in place:

- questions about critical thinking and clinical instruction were set in a format as simple as possible to reduce ambiguity and add to precision of the study (Babbie \& Mouton, 2001:119);

- close-ended questions were used, where participants had specific limits in which they could respond to ensure consistency in responses (Babbie \& Mouton, 2001:119);

- ample time was allowed to complete questionnaires so that participants could think about their responses;

- questionnaires were administered in a consistent manner; and

- the characteristics of the participants in the pre-test were the same as the ones in the study. Student nurses and nurse educators from the same population as the study were included in the pilot study.

For ensuring validity the following measures applied:

- content and face validity were ensured by a proper literature study where correct references were made and an interpretation of literature took place (Babbie \& Mouton, 2001:121);

- experts in the area of clinical teaching were involved in to validate the instrument to ensure construct validity (Babbie \& Mouton, 2001:121);

- questions relevant to critical thinking and clinical instruction were asked to ensure content validity (Babbie \& Mouton, 2001:123); and

- questions in the instruments were compared against relevant literature to ensure that the exact information would be gathered.

\section{Data collection}

One questionnaire was distributed to all clinical nurse instructors. In Windhoek the questionnaires were distributed by hand, while the questionnaires for the Northern participants were mailed to a research assistant and collected by the latter. Concepts included in the questionnaire are explained and motivated in Table 2.
The pilot study was part of the planning phase of the research (Burns \& Grove, 1997:775). The questionnaires were piloted to ascertain clarity, establish content validity and refine the data collection tool. Revision and refinement to questions were made once the pilot study was conducted. The pilot subjects were not included in the research sample although they were from the same population. The questionnaires were thoroughly discussed with the statistician before final distribution.

\section{Data analysis}

Data were first analysed by hand where-after specific items were analysed by the statistician. Descriptive statistics were applied. Frequencies and mean values were used. These results were presented in relevant figures.

\section{ETHICAL CONSIDERATIONS}

Permission to conduct the study was obtained from the Permanent Secretary of the Ministry of Health and Social Services, as well as from Medical Superintendents of the training hospitals where data were collected.

Anonymity during completion of the questionnaire was ensured since participants did not have to fill in their names. The researcher was assisted in the distribution and collection of the questionnaires, which supported anonymity. Although no written consent was obtained from the participants, participation in the research was voluntary and only participants, who in principle agreed, completed a questionnaire.

\section{LIMITATIONS OF THE STUDY}

A few limitations were observed during the study:

- A limited understanding of English could have hampered the participants' understanding of the questions

- Close-ended questions were included where the participant was confined to specific options about critical thinking. Some open-ended questions could have been included on the perception of participants about critical thinking.

FINDINGS AND CONCLUSIONS

\section{Pilot study}


Throughout the study the researcher intended to determine the contribution of the clinical nurse instructor towards the development of critical thinking abilities of student nurses.

The findings and conclusions are discussed according to the objective namely:

- to explore and describe the contribution of the clinical nurse instructor to the development of critical thinking in student nurses.

The findings are based on the analysis of the concepts of Table 2, which were utilised in the construction of the instrument. These concepts were regarded as being representative of the focus of the objective. Burns and Grove (1997:625) are of the opinion that the dissemination of research findings leads to the enhancement of the knowledge of a discipline, which in this case refers to critical thinking in nursing.

For the analysis of each concept, certain applicable items were constructed.

The first concept is:

\section{The fostering of inquisitive strategies and open-mindedness}

Legally and ethically this concept needs to be internalised quite early in a registered nurse's practice. Information technology is changing rapidly and together with the principle of accountability, a registered nurse has to be inquisitive and have an open mind. Therefore the developing of these two skills (being inquisitive and open-minded), cannot commence too soon for a student nurse.

To analyse this concept, two (2) items were constructed, namely:

- $\quad$ assessing the possibility/opportunity for stating own view point by student nurses

- $\quad$ assessing the possibility/opportunity for student nurses to question/challenge activities/ assignments.

It was found that $26 \%(n=36)$ of the participants (clinical nurse instructors) indicated that they create the possibility/opportunity for student nurses to express their own view points.
On the item on the opportunity to question or challenge activities or assignment, $45 \%(n=55)$ indicated that they do provide opportunities or possibilities for students to question or challenge activities.

Leino-Kilpi (1990:193) is of the opinion that in order to teach students to think critically and with an open mind the instructors should show a critical-inquiry-orientated attitude towards their work. A student should cultivate a critical perspective that involves the asking of many analytical questions as a way of life to ensure that the best choice from a number of alternatives has been made (Bethune \& Jackling, 1997:1007).

In this study it was concluded that only $45 \%$ of the clinical nurse instructors try to foster a "questioning/ critical" mind by allowing students to question assignments or even challenge assignments or activities. In addition only $26 \%$ foster the development of own viewpoint by students.

\section{Fostering of an analytic process to prob- lem solving}

Three items dealt with this concept namely:

- application of problem solving during patient care;

- ethical decision-making; and

- analysis of problems encountered during caring activities.

The results of these three items are depicted in Figure 2.

It was found that $42 \%(n=52)$ of the participants did foster problem solving activities during caring activities. However, only $29 \%(n=40)$ acknowledge that they assisted students during the analysis of problems encountered with the caring activities while $28 \%(n=39)$ assisted with ethical decision-making.

For a nurse to be a critical thinker in the practical situation means the intentional engagement with a problem at hand (Chenoweth, 1998:283). The nurse instructor should ask questions that suits into the development of intellectual integrity amongst nursing students, who will then, as a result of critical thinking, be self-reflective and account for rendering of patient care (Beekman, 2000:38). 
The health sector, and specifically the practice of nursing in Namibia and elsewhere, are confronted with ethical dilemmas like shortage of materials, equipment, personnel, as well as with life and death decisions. To ensure safe practice in a caring manner and within the mentioned obstacles and limitations, the nurse needs to be an analytical thinker.

It is concluded that the fostering of an analytic problem solving process is not optimally achieved. It could be argued that specifically ethical decision-making and analysis of problems are skills which should be emphasised more.

\section{The fostering of independent decision- making}

Two items were constructed on this concept, namely the making of independent judgments and the making of decisions with regard to record-keeping. The results are illustrated in Figure 3.

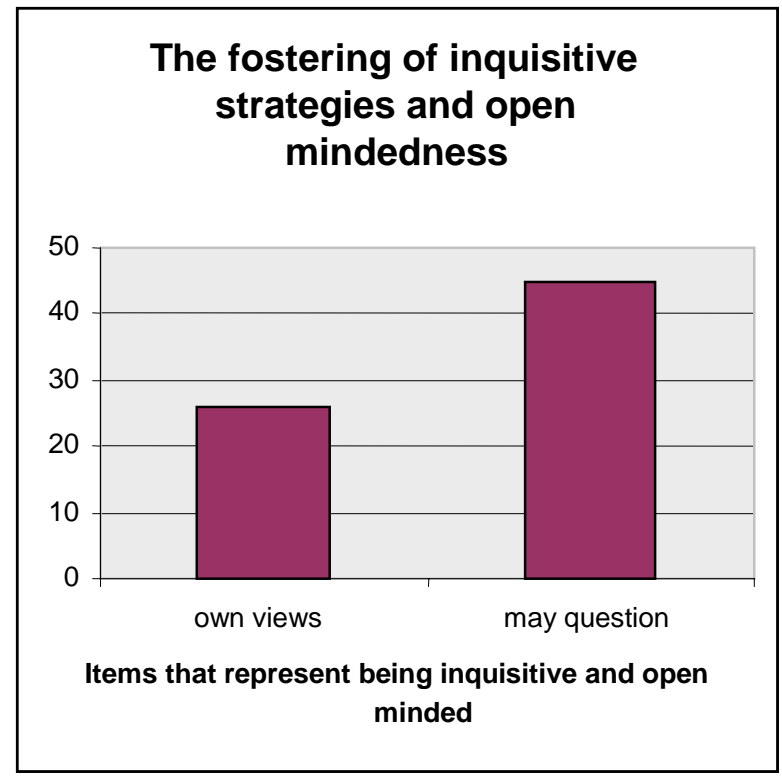

Figure 1: The fostering of inquisitive strategies and open-mindedness

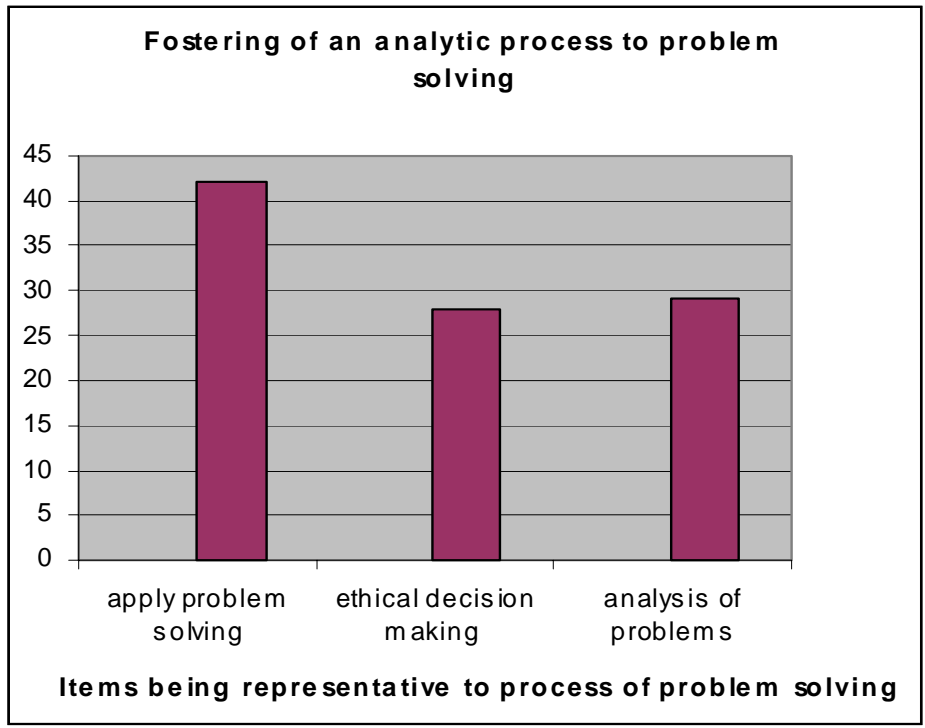

Figure 2: Fostering of an analytic process to problem solving 


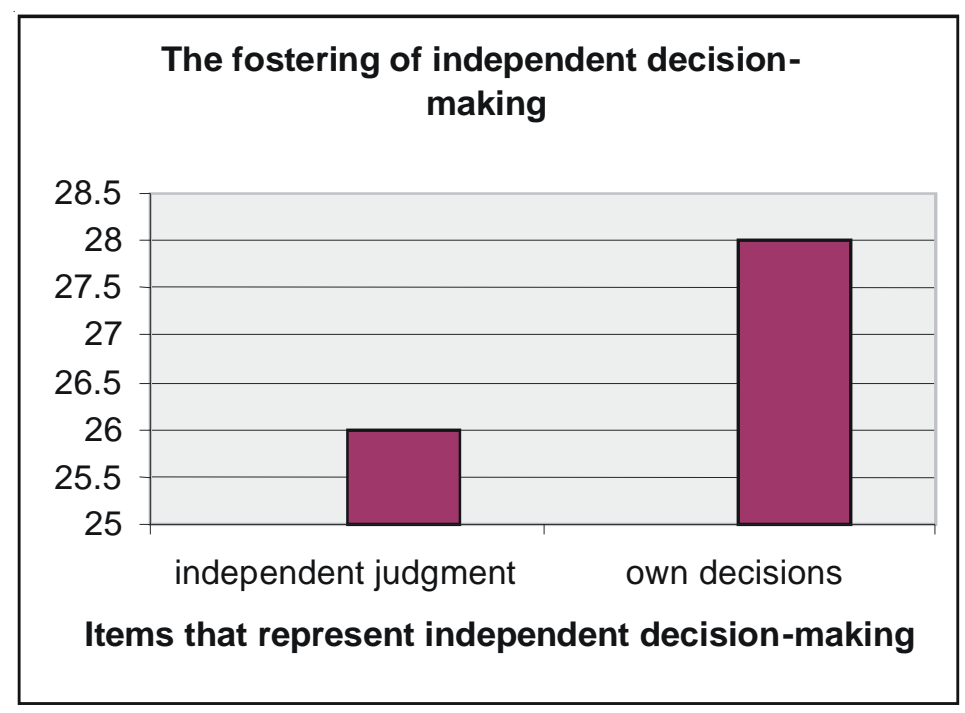

Figure 3: Fostering of independent decision-making

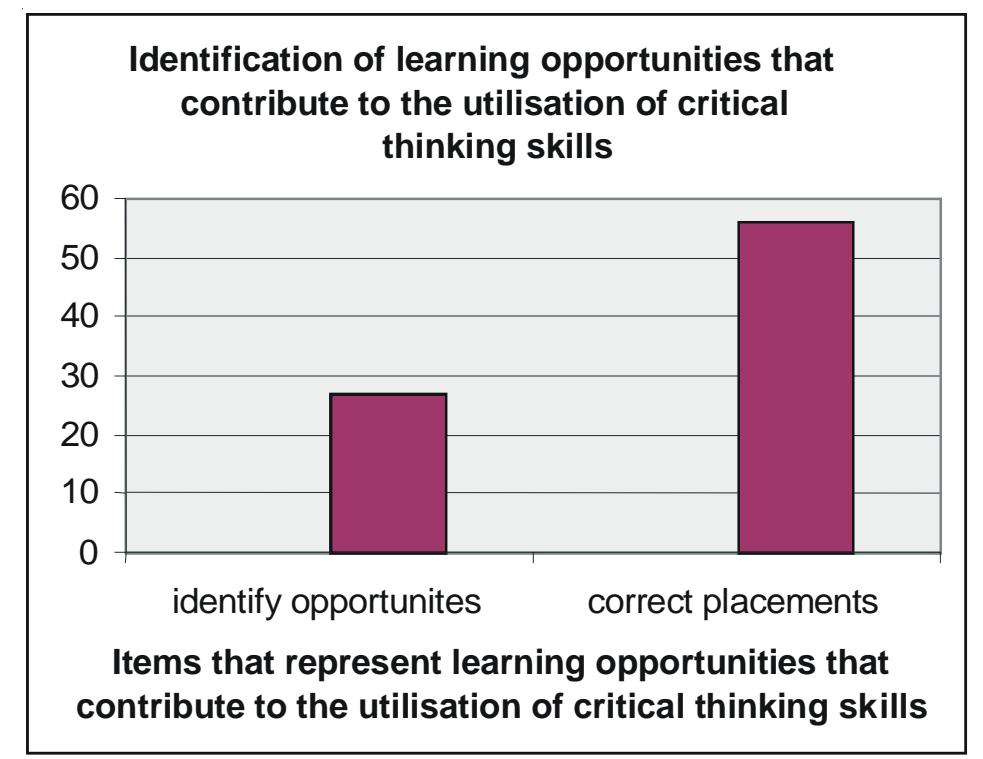

Figure 4: Identification of learning opportunities that contribute to the utilisation of critical thinking skills

The findings indicated that only $26 \%(n=37)$ of the participants fostered independent judgment while $28 \%$ $(n=38)$ allowed for own decisions to be taken with regard to record-keeping.

This is in contrast with what is expected from students and for that matter for future registered nurses as depicted in the literature. Both the above-mentioned items in Figure 3 have to do with personal power. Personal power is the key to success to enable the student to practice effectively (Bezuidenhout \& Jooste, 1994:58). According to Mpaka and Uys (1999:16) it is through teaching critical thinking that students are empowered to control their own destiny. Despite the presence of the clinical nurse instructor, the student needs to experience an attitude of freedom, and have the opportunity to risk without fear of personal failure and without the risk of harming patients. The learning environment of students should allow them to express anxieties and receive support from personnel on unit level (Miller \& Malcolm, 1990:16).

It is concluded, that based on the results, independent decision-making is not optimally promoted, and that the expectations as depicted in the literature, would not be fully realised. 
The identification of learning opportunities that contributes to the utilisation of critical thinking skills

Two items focused on this activity namely identification of learning opportunities which foster critical thinking per se, and the delegation of students to situations where critical thinking may be required. The results are depicted in Figure 4.

It was found that $27 \%(n=36)$ of the clinical nurse instructors indicated that they do identify suitable learning opportunities, while with regard to the appropriate placement of students, the response was higher. Here $56 \%(n=71)$ acknowledged that they do place the students in places they believe would contribute to the development of critical thinking.

The clinical nurse instructor does have an important function with regard to the creation of applicable learning opportunities. This function is also motivated by Rowles and Brigham (1998:247), they state that the clinical nurse instructors have to re-examine the best way to teach and empower students for learning in the clinical area in a special type of environment. This environment should fosters opportunities for students to think through challenging and worthwhile problems.

From the analysis it appeared that clinical nurse instructors do place students in appropriate learning environments, although an argument could be that it should approach a $100 \%$ adherence instead of only $56 \%$, as the time that they have to rotate through different clinical settings are limited, and possibilities to "re-visit" clinical areas might not always be possible.

The identification of learning opportunities to foster critical thinking is however not optimal.

\section{The fostering of a holistic approach to nursing care}

One question dealt with this issue. The clinical nurse instructors were asked how students are guided to enable them to form a holistic picture about their patients. It was found that only $34 \%(n=46)$ of the clinical nurse instructors promoted a holistic approach.

The issue of holism is a very crucial issue in nursing, especially when the principle of patient advocacy had to be practiced. It is the nurse who has to stand in for the patient and try and provide meaning about diverse treatment interventions, and a multidisciplinary team, all with different approaches and philosophies of care and caring.

This aspect of holism is eloquently put by Inouye and Flannely (1998:69). They state that the nursing student has to examine all given data about all dimensions of a patient. This is necessary to draw inferences, make deductions and evaluate weak and strong points about decisions which may affect the whole scenario of nursing care of a patient. Nurses must therefore be able to defend their cases in discussing the treatment of all dimensions of a patient to obtain the best possible option for a patient in totality.

It is concluded that that the fostering a holistic approach is not optimally achieved.

\section{RECOMMENDATIONS}

In terms of the stated objectives the researcher recommends that an in-service programme be offered to all categories of clinical nurse instructors and that the programme should include the following aspects:

- The importance of the contribution of the clinical nurse instructor in the development of critical thinking in student nurses.

- The impact of a positive role model on the development of the critical thinking skills of the student.

- The empowerment of students through clinical education, in order to identify learning opportunities during their clinical practice, through which they can practice critical thinking.

- The application of a holistic approach to nursing care where analytical thoughts to problem solving are promoted.

Critical and creative thinking skills are becoming increasingly important for nurses because the world with its health problems and its health care systems is becoming more and more complex, and the rate of change continues to escalate (Holbert \& Abraham, 1988:26).

In order for nurse practitioners in Namibia to align themselves with the pace of change, they need to become 
critical thinkers who can analyse situations as they arise and the nurse health educators should intensify their efforts to prepare future nurses with requisite skills for nursing practice by developing critical thinking skills in nursing students.

\section{CONCLUSION}

The final conclusion with regard to the contribution made by the clinical nurse instructor in the development of critical thinking of student nurses is that it is not optimal and that it should be developed and enhanced. It has become clear that critical thinking in clinical instruction is a developmental process that should be nurtured through life to become part of life.

It is accepted worldwide that without an inquiring and insightful workforce health improvements will not be achieved (Price, 2004:46).

The ability to think critically in the clinical practice area does not happen overnight but occurs over a period of time with the contribution of clinical nurse instructors. Their role is to foster inquisitive habits, open-mindedness and prudent decision-making which should result in a willingness to reconsider decisions, and to focus on inquiry that will be the best treatment and management for the patient at stake.

Nowadays where accountability in nursing is stressed, professional nurses need to know how to make decisions correctly. In order to serve clients and confront urgent health problems the professional nurse must be able to think critically. This however is a process that should be nurtured through life because health problems become more and more complex and the rate of change continues to escalate (Holbert \& Abraham, 1988:26; Mpaka \& Uys, 1999;16).

\section{REFERENCE LIST}

BABBIE, E \& MOUTON, J 2001: Practice of social research. Cape Town: Oxford University.

BANDMAN, EL \& BANDMAN, B 1988: Critical thinking in Nursing. Appleton: Lange.

BEEKMAN, L 2000: Problem solving and decision-making strategies and skills. A co-curriculum teaching thinking skills for nursing students. Durban: Butterworths.

BETHUNE, E \& JACKLING, N 1997: Critical thinking skills: The role of prior experience. Journal of Advanced Nursing, 26:10051012.

BEZUIDENHOUT, M \& JOOSTE, K 1994: Empowering the nurse supervisor. Nursing RSA Verpleging, 9(7):36-39.

BRINK, HIL 1996: Nursing education. Study Guide 2 for NUE 204 E and NED 204-H. Pretoria: UNISA.

BURNARD, P \& MORRISON, P 1993: Survival guide for nursing students. Durban: Butterworths.

BURNS, N \& GROVE, SK 1997: The practice of nursing research; $3^{\text {rd }}$ edition. Philadelphia: WB Saunders.

CHENOWETH, L 1998: Facilitating the process of critical thinking for nursing. Nurse Education Today, 18:281-292. COMMUNITY COLLEGE OF RHODE ISLAND. 2003. CCRI http:// www.ccri.edu/nursing/concepts.html.

CONGER, MM \& MEZZA, I 1996: Fostering critical thinking in nursing students in the clinical setting. Nurse Educator, 21(3):12.

DULDT, BW 1994: Critical thinking (Reprinted from a two-part article published in Research Pulsations, 1(6) Bi-monthly faculty news letter, School of Nursing. East Carolina University). Nurse Educator, 19:8-9.

GARBERS, JG 1996: Effective research in the human sciences. Pretoria: Van Schaik.

HARBISON, J 1991: Clinical decision-making in nursing. Journal of Advanced Nursing, 16:404-407.

HARDEN, J 1996: Enlightenment, empowerment and emancipation; the case for critical pedagogy in nurse education. Nurse Education Today, 16:32-37.

HILL, SS \& HOWLETT, HA 1997: Success in practical nursing. Personal and vocational issues. Philadelphia: WB Saunders.

HOLBERT, CM \& ABRAHAM, C 1988: Reflections on teaching generic thinking and problem solving. Nurse Educator, 13(2):2327.

INOUYE, J \& FLANNELY, L 1998: Inquiry-based learning as a teaching strategy for critical thinking. Clinical Nurse Specialist, 12(2):67-72.

JONES, SA \& BROWN, LN 1991: Critical thinking: Impact on nursing education. Journal of Advanced Nursing, 16:529-533.

LEINO-KILPI, H 1990: Self-reflection in nursing teacher education. Journal of Advanced Nursing, 15:192-195.

MALEK, CJ 1986: A model for teaching critical thinking. Nurse Educator, 11(6):10-23.

MANZINI, HN 1988: The role and responsibility of the nurse preceptor in the education and training of student nurses. Pretoria: UNISA. (Unpuiblished Masters Thesis).

MIERS, M 1990: Developing skills in decision-making. Nursing Times, 86(30):30-32.

MILLER, MA \& MALCOLM, NS 1990: Critical thinking in the nursing curriculum. Nursing and Health Care, 11(2):67-73.

MPAKA, NM \& UYS, LR 1999: The critical thinking ability of diplo- 
mats from different types of bridging programmes. Curationis, 22(3):15.

NORRIS, SP \& ENNIS, RH 1985: Evaluating critical thinking. The practitioners guide to teaching series. Pacific Grove: Critical Thinking Press and Software.

NORTON, B 1998: Selecting learning experiences to achieve curriculum outcomes. (In: Billings, DM \& Halstead, JA eds 1998: Nursing. Tokyo: WB Saunders, pp 151-169).

NURSING ACT No 30 of 1993: Government Gazette of Namibia No 764.

PRETORIUS, L 2001: The role of the clinical nurse instructor in the development of critical thinking in student nurses in Namibia. Windhoek: University of Namibia. (Unpublished Masters Thesis). PRICE, A 2004: Encouraging reflection and critical thinking in practice. Nursing Standard, 18(47):46-47.

RICHARDSON, V 1998: The diverse learning needs of students in teaching. (In: Billings, DM \& Halstead, JA eds 1998: Nursing. Tokyo: WB Saunders, pp 17-31).

ROWLES, CJ \& BRIGHAM, C 1998: Strategies to promote critical thinking and active learning. (In: Billings, DM \& Halstead, JA ed. 1998: Nursing. Tokyo: WB Saunders, pp 247-270).

SHIN, KR 1998: Critical thinking ability and clinical decision-making skills among senior nursing students in associate and baccalaureate programs in Korea. Journal of Advanced Nursing, 27:414418.

SCHWEER, JE \& GEBBIE, KM 1976: Creative teaching in clinical nursing. Philadelphia: Mosby.

SHAH, HS \& POLIFRONI, C 1992: Preceptorship of CNS students. An exploratory study. Clinical Nurse Specialist. 6:41-46.

TIWARI, A \& LAI, P 2002: Promoting nursing students' critical thinking through problem-based learning. http://www.ecu.edu.au/conference/herdsa/main/papers/nonref.pdf.AgnesTiwari

VAN HOOZER, H 1987: The teaching process. New York: Prentice Hall.

VAN DEN BERG, MES 2000: Is there a need for critical thinking skills modules at tertiary level? SAHJE/SATHO, 14(1):96-107. 